\title{
Tissue reaction to Aroeira (Myracrodruon urundeuva) extracts associated with microorganisms: an in vivo study
}

\section{Carlos Roberto Emerenciano BUENO ${ }^{(a)}$ Diego VALENTIM ${ }^{b}$ \\ Élerson Gaetti JARDIM JUNIOR(a) \\ Daniela Nardi MANCUSO(c) \\ Gustavo SIVIERI-ARAUJO(a) \\ Rogerio Castilho JACINTO(a) \\ Luciano Tavares Angelo CINTRA ${ }^{(a)}$ \\ Eloi DEZAN-JUNIOR ${ }^{(a)}$}

(a) Universidade Estadual Paulista- UNESP, Araçatuba School of Dentistry, Department of Endodontics, Araçatuba, SP, Brazil.

(b) Centro Universitário do Distrito Federal UDF, School of Dentistry, Department of Endodontics, Brasilia, DF, Brazil.

(c)The Specialist Endodontic Centre Emery \& Mancuso, Portsmouth, United Kingdom.

Declaration of Interests: The authors certify that they have no commercial or associative interest that represents a conflict of interest in connection with the manuscript.

Corresponding Author:

Eloi Dezan Junior

E-mail: dezan@foa.unesp.br

Submitted: Sep30, 2017

Accepted for publication: March 21, 2018

Last revision: Apr 10, 2018
Abstract: Based on aroeira's (Myracrodruon urundeuva) antimicrobial activity and a future trend to compose intracanal medication, the aim of this study was to assess in vivo inflamatory tissue response to the extracts by edemogenic and histological analysis containing inactivated facultative and anaerobic microorganisms. For edema quantification, eighteen animals were divided into three groups $(n=3$, periods: 3 and 6 hours) and $0.2 \mathrm{~mL}$ of $1 \%$ Evans blue per $100 \mathrm{~g}$ of body weight was injected into the penile vein under general anesthesia. After 30 min the animals received a subcutaneous injection in the dorsal region of aqueous or ethanolic extract of aroeira or saline (control) containing inactivated bacteria. Samples were collected, immersed in formamide for $72 \mathrm{~h}$, and evaluated by spectrophotometry $(630 \mathrm{~m})$. For histological analysis, polyethylene tubes with the extracts were implanted in the dorsal of 30 male rats. Analysis of the fibrous capsule and inflammatory infiltrate were performed after 7 and 30 days. The aqueous extract group induced less edema in both postoperative periods compared to the other groups, but the differences were not significant $(p>0.05)$. Tissue repair was significantly better after 30 days than after 7 days $(p<0.01)$. The aqueous solution showed less inflammatory response than the ethanolic solution $(p<0.05)$, with tendency for better results than control after 7 days. After 30 days, the response to both extracts was similar to control. The aqueous and ethanolic aroeira extracts containing inactivated microorganisms showed a trend for better results than saline, even when associated with microorganisms, and facilitated the tissue repair process.

Keywords: Inflammation; Edema; Plants, Medicinal; Plant Extracts.

\section{Introduction}

The role of microorganisms, their products and by-products is observed in the canal system ${ }^{1,2,3,4}$ in teeth with pulpal necrosis and periapical disease. ${ }^{5}$ Due to the complexity of the root canal system, the mechanical action of the instruments is not able to complete eliminate the microorganisms present in isthmus, lateral canals neither deep in the dentinal tubules ${ }^{6}$ nor those located in areas of external reabsorption, protected by apical biofilm. ${ }^{7}$ Therefore, the use of an inter-appointment medication is often essential to 
reduce the bacterial load. ${ }^{8}$ With this purpose, many medication protocols have been used over the years, including the use of paramonoclorofenol, phenolic derivatives, aldehydes and steroids in combination with antibiotics, and all proved antimicrobial activity or biological compatibility, but rarely both. ${ }^{5}$ Calcium hydroxide has been the most significant medication used through many years and is still used as root canal dressings for both deciduous and permanent teeth.

Recently, studies using plant extracts of araçá (Psidium cattleianum) showed the antimicrobial activity, even against $S$. mutans ${ }^{11}$ and its biocompatibility as extract with inactivated microorganism ${ }^{12}$ or when used with calcium hydroxide. ${ }^{13}$

Myracrodruon urundeuva, (also known as aroeirado-sertão), is a plant that belongs to the Anacardiaceae family, and is native of South America. ${ }^{14}$ It is one of the five most important native species used for local therapeutic indication $\mathrm{s}^{15}$ demonstrating analgesic and anti-inflammatory properties. ${ }^{16}$ Recently, aroeira's extracts were reported to have potent antimicrobial activity against oral microorganisms ${ }^{10}$, while presenting a satisfactory tissue response. ${ }^{10,17}$

Microorganisms may present different characteristics, such as structural, metabolic or pathogenic and its contact with periapical region stimulate an inflammatory response. ${ }^{18}$ The presence of bacteria, endotoxins (lipopolysaccharides), products of bacterial metabolism, even the presence of dead bacteria, induces an inflammatory response, leading to processes that may develop a periapical disease. ${ }^{19}$

Therefore, the aim of this study was to evaluate in vivo, the edema inflammatory tissue reaction to aqueous or ethanolic extracts of aroeira (Myracrodruon urundeuva) associated with inactivated microorganisms. The null hypothesis was that the association of the plant extracts with the microorganism would evoke a severe inflammatory reaction.

\section{Methodology}

\section{Animals}

Thirty-eight Wistar (Rattus norvegiccus) male rats, 60 days old and 250-300 g, were obtained from Araçatuba School of Dentistry Vivarium - UNESP. The animals were housed in temperature-controlled rooms and received water and food ad libitum through the pre-experimental period. The care of the animals was performed according to the Araçatuba School of Dentistry Ethical Committee on Animal Research (Process \#2007-003230), which approved the project before the beginning of the experiments.

\section{Plant extract preparation}

The Aroeira (Myracrodruon urundeuva) plants were obtained from ecological reserves in Carolina, Maranhão state in Brazil. The leaves were collected if they appeared healthy and free of disease and pests. After collection, the plants were washed in water, dried at room temperature and in placed in a heater at $37^{\circ} \mathrm{C}$ until they became dry and friable, as previous protocols..$^{13,17,20}$ Subsequently, they were pulverized.

The ethanolic and aqueous extracts were prepared according to the methodology described by Machado et al. ${ }^{17}$ as follow:

Ethanolic extract: $20 \mathrm{~g}$ of leaf powder were mixed to $250 \mathrm{ml}$ of $80 \%$ ethanol. The flask was mixed vigorously and manually for three minutes, five times a day, for 12 days. Subsequently the filtration was performed. The product was sterilized by filtration in cellulose ester membrane of $0.22 \mu \mathrm{m}$ (Millipore ${ }^{\circledR}$ ).

Aqueous extract: $20 \mathrm{~g}$ of leaf were added to 250 $\mathrm{ml}$ of distilled water, boiled at $100^{\circ} \mathrm{C}$ for 5 minutes and kept at $55^{\circ} \mathrm{C}$ for 1 hour at room temperature for 72 hours, agitated every 24 hours. The solution was filtered and sterile as mentioned before.

\section{Microorganisms association}

All microorganisms (Table 1) were grown in BHI and incubated under anaerobiosis conditions (90\% N2 $+10 \mathrm{CO} 2)$, at $37^{\circ} \mathrm{C}$ for $24-48$ hours. After this period, a suspension containing $10^{\circ} \mathrm{cel} / \mathrm{mL}$ was prepared, and subjected to 3 successive washes in saline solution by centrifugation at $14,000 \mathrm{rpm}$ for 5 minutes, to remove residues of the culture medium. Then, the precipitate was re-suspended in $3 \mathrm{~mL}$ of saline solution and maintained by 30 minutes in water bath at $60^{\circ} \mathrm{C}$, for bacterial inactivation.

The microbial suspension containing $5,10^{6} \mathrm{cel} / \mathrm{mL}$ of each inactivated bacteria was re-suspended in $1 \mathrm{ml}$ of each experimental solution; saline, ethanolic and aqueous extract of aroeira, constituting the experimental groups: 
Table 1. Bacterial species used for the preparation of the suspension.

\begin{tabular}{llll}
\hline Bacterial species & Strain provance & Morphotype & Physiology \\
\hline Porphyromonas gingivalis & ATCC 33277 & Gram-negative & Anaerobes \\
Peptostreptococcus micros & ATCC 33270 & Gram positive & Anaerobes \\
Prevotella intermedia & ATCC 25611 & Gram-negative & Anaerobes \\
Fusobacterium nucleatum & ATCC 25586 & Gram-negative & Anaerobes \\
Porphyromonas endodontalis & ATCC 35406 & Gram-negative & Anaerobes \\
Enterococcus faecalis & ATCC 29212 & Gram positive & Facultative \\
\hline
\end{tabular}

a. $1 \mathrm{ml}$ Aqueous extract $+5,10^{6} \mathrm{cel} / \mathrm{mL}$ of each reference strain;

b. $1 \mathrm{ml}$ Ethanolic extract $+5,10^{6} \mathrm{cel} / \mathrm{mL}$ of each reference strain;

c. $1 \mathrm{ml}$ Saline $+5,10^{6} \mathrm{cel} / \mathrm{mL}$ of each reference strain (control).

\section{Edemogenic test - immediate reaction}

For edema quantification, 18 Wistar rats were divided into 3 experimental groups, with 2 analysis periods ( $3 \mathrm{~h}$ and $6 \mathrm{~h}$ ). The animals were anesthetized with xylazine $(10 \mathrm{mg} / \mathrm{kg})$ and ketamine $(25 \mathrm{mg} / \mathrm{kg})$, and received an intravenous injection of 1\% Evan's blue (Evan's Blue; Difco Lab, Detroit, USA) with a concentration of $0.2 \mathrm{~mL} / 100 \mathrm{~g}$ body weight, in the penile vein. After $30 \mathrm{~min}, 0.1 \mathrm{~mL}$ of the inactivated bacteria-containing extracts, or saline, was injected in the dorsum, using the median line as a reference. After 3 and $6 \mathrm{~h}$, the animals were euthanatized by an anesthetic overdose and a tissue fragment standardized with $23 \mathrm{~mm}$ diameter, containing a blue halo in the center, was dissected, macerated, and immersed in $4 \mathrm{~mL}$ of formamide for 72 $\mathrm{h}$ at $45^{\circ} \mathrm{C}$, and filtered for spectrophotometric analysis at a wave length of $630 \mathrm{~nm} \cdot$. $^{1720}$

\section{Polyethylene tubes}

Sixty polyethylene tubes (Abbott Lab of Brazil, Sao Paulo, Brazil) with $1.0 \mathrm{~mm}$ internal diameter $\mathrm{x}$ $1.6 \mathrm{~mm}$ outer diameter $\times 10 \mathrm{~mm}$ length, were obtained and the groups were accommodated inside.

In order to prevent leakage, one end of the tube was sealed with $1 \mathrm{~mm}$ of gutta percha. Then, a sterile paper cone with a diameter compatible with the tube, was inserted, but accurately cut $0.2 \mathrm{~mm}$ below the tube length, avoiding direct contact with the tissue, offering conditions to retain the solutions inside the tubes.
The tubes were submitted to ethylene oxide sterilization process ${ }^{17}$ (Oximed - São José do Rio Preto, Brazil).

\section{Subcutaneous implant}

For the histological analysis, 20 male Wistar albino rats $(n=10)$ were divided into groups according to the experimental period of analysis ( 7 and 30 days). The anesthetized animals were shaved in the back and the area was disinfected with a 5\% iodine solution (Riodente, Rioquímica, São José do Rio Preto, Brazil). A $2 \mathrm{~cm}$ longitudinal incision was made in the dorsal region with a \#15 blade. The tubes were implanted and the skin was closed with a 4/0 silk suture (Ethicon, Johnson \& Johnson Produtos Profissionais Ltda., São José dos Campos, Brazil). Each animal received 3 implants containing the aqueous, ethanolic aroeira extracts and saline with inactivated bacteria, implanted in the right and left side of the animals' subcutaneous tissue. After the experimental time periods of 7 and 30 days, the animals were euthanatized by anesthetic overdose and the tubes with the surrounding tissue were removed and fixed in $10 \%$ formalin at $\mathrm{pH} 7.0$ for 48 hours and then washed in water for 12 hours. The pieces were dehydrated, clarified, and included in paraffin, followed by longitudinally cut with $6 \mu \mathrm{m}$ thickness, to be stained with hematoxylin and eosin for microscopic analysis (Leica, Germany).

The results obtained for inflammatory tissue response from extracts was compared to those of the control group under 100X and 400X magnification, to measure the thickness of the fibrous capsule and to count inflammatory cells, respectively. A descriptive analysis was performed for the three experimental groups. Tissue reactions at the open end of the tubes were scored according to previous studies ${ }^{13,20,21}$ as 
follows: 0 , few inflammatory cells or no reaction; 1 , less than 25 cells and mild reaction; 2 , between 25 and 125 inflammatory cells and moderate reaction; and 3 , 125 or more inflammatory cells and severe reaction. Fibrous capsules were considered thin when $<150$ $\mu \mathrm{m}$ and thick when $>150 \mu \mathrm{m} \cdot{ }^{13,20,21,22}$

\section{Statistical analysis}

Edemogenic test results were analyzed with an ANOVA and Tukey's test, and the Mann-Whitney and Kruskal-Wallis tests were used to analyze the histological data, using the SigmaPlot software (Systat V12.0). The significance level was set to $95 \%$ for all analyses $(\mathrm{p}<.05 \%)$.

\section{Results}

\section{Edemogenic analysis}

Although there was no statistically significant difference $(p>0.05)$ between the two experimental time periods ( $3 \mathrm{~h}$ and $6 \mathrm{~h}$ ), the inactivated bacteria-containing ethanolic aroeira extract induced more edema than the aqueous extract or saline solution $(p<0.05)$ (Figure 1).

\section{Histological analysis}

Histological analysis was conducted after 7 and 30 days, and a significant difference was observed for all three groups $(p<0.01)$ with decreased inflammation in the 30-day period (Figure 2).

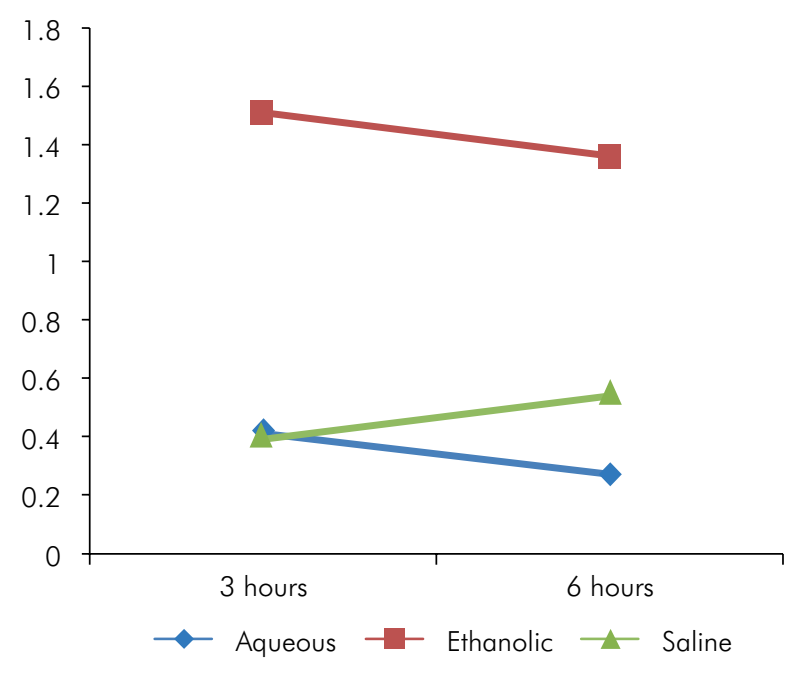

Figure 1. Graphical representation of the average edema value in both experimental time periods of 3 and 6 hours.

\section{Saline + Bacteria - 7 days}

Theinflammatory response achieved a median score 3. The capsule was thick (>150 $\mu \mathrm{m})$ with inflammatory cells, predominated with macrophages, lymphocytes some neutrophils, and other mononucleated cells. Presence of rare fibroblasts, interspersed with few collagenous fibers, which appeared in a disorganized and complex arrangement (Figure 3A, Table 2).

\section{Saline + Bacteria - $\mathbf{3 0}$ days}

This group presented a higher degree of tissue organization (median score 2) when compared to 7 days period, presenting a thin fibrous capsule composed of fibroblasts arranged parallel to the implant area. A macrophages conglomerate on the surface was also observed in contact with the implant area and presence of some lymphocytes and few other inflammatory cells. No sample showed capsule thickness greater than $150 \mu \mathrm{m}$ (Figure 3B; Table 2)

\section{Aqueous Aroeira + Bacteria - 7 days}

Most of samples in this group presented severe inflammation (median score 3 ) in a thick capsule, with predominance of macrophages and numerous lymphocytes. A dense network of small caliber blood vessels within the fibrous capsule and larger adjacent tissues were observed. All samples had a capsule thickness greater than $150 \mu \mathrm{m}$ (Figure 3C; Table 2).

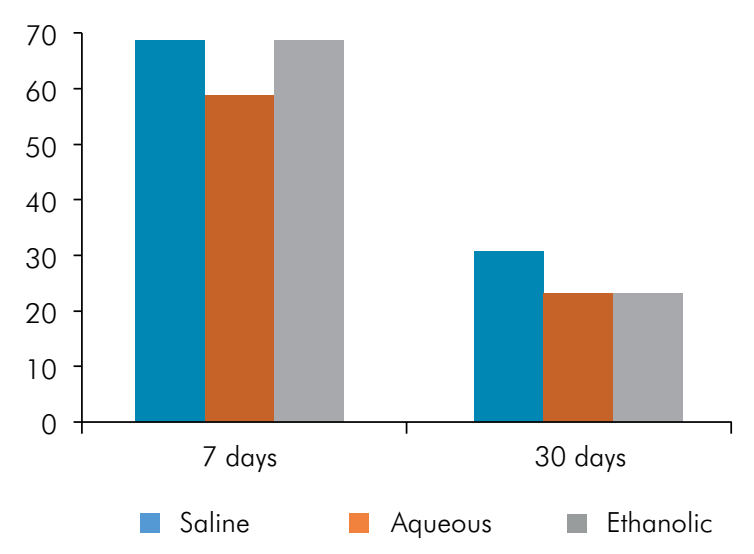

Figure 2. Graphical representation of the position occupied by the average scores in the two experimental periods, for the three groups. 

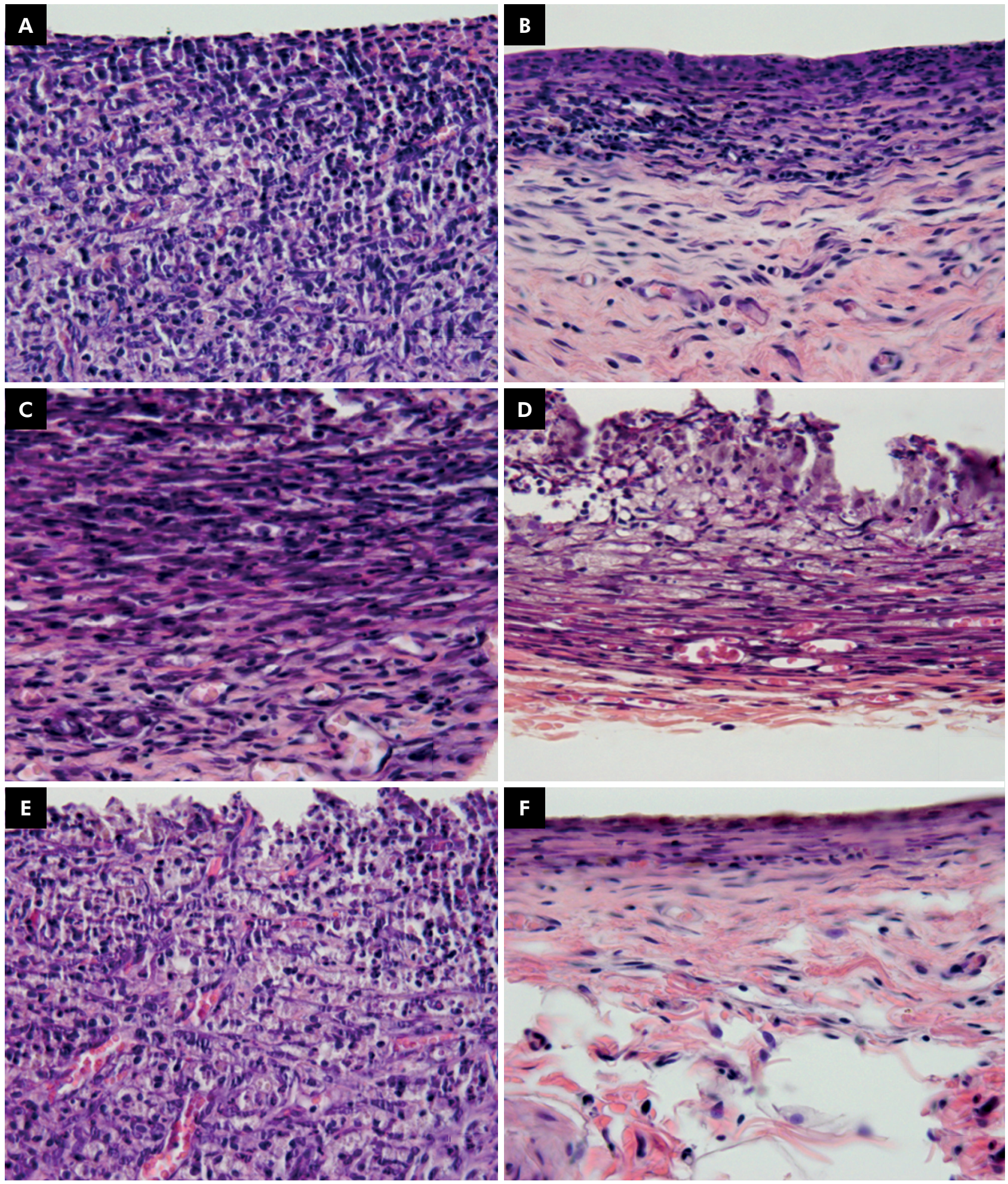

Figure 3. Subcutaneous tissue reactions in the experimental groups. Control group (A): Saline + microorganisms 7 days; (B) 30 days; Aqueous extract + microorganisms; (C) 7 days and (D) 30 days; Ethanolic extract + microorganisms; (E) 7 days and (F) 30 days. At 7 days period, all the groups showed severe inflammatory response, with fibroblasts and collagen fibers in a disorganized distribution. After 30 days, all groups (B, D, F) showed well organized connective tissue, and decreased number of inflammatory cells and capillaries. 
Table 2. Percentage of samples in each group categorized according to the inflammatory score and the rating thickness of fibrous capsule.

\begin{tabular}{|c|c|c|c|c|c|}
\hline \multirow{2}{*}{ Variable } & \multicolumn{4}{|c|}{ Score (\%) } & \multirow{2}{*}{ Capsule } \\
\hline & 0 & 1 & 2 & 3 & \\
\hline \multicolumn{6}{|l|}{7 days } \\
\hline Saline (control) & 0 & 0 & 0 & 100 & Thick \\
\hline Aqueous extract & 0 & 0 & 25 & 75 & Thick \\
\hline Ethanolic extract & 0 & 0 & 0 & 100 & Thick \\
\hline \multicolumn{6}{|l|}{30 days } \\
\hline Saline (control) & 0 & 20 & 50 & 30 & Thin \\
\hline Aqueous extract & 0 & 85 & 15 & 0 & Thin \\
\hline Ethanolic extract & 0 & 90 & 10 & 0 & Thin \\
\hline
\end{tabular}

\section{Aqueous Aroeira + Bacteria - $\mathbf{3 0}$ days}

The microscopic images indicate a decrease of the inflammatory infiltrate (median score 1) compared to the period of 7 days. The inflammatory cells agglomerate was replaced by a thin fibrous capsule. It was possible to identify the presence of some fibrocytes and some few fibroblasts among the collagen fibers. In general, the macrophage layer was more discrete and the amount of lymphocytes and other mononuclear cells was diminished. No capsule was thicker than $150 \mu \mathrm{m}$ (Figure 3D; Table 2)

\section{Ethanolic Aroeira + Bacteria - 7 days}

The fibrous capsule was also thick, rich in macrophages, lymphocytes, few leukocytes and other mononuclear inflammatory cells (median score 3). Some plasmocytes could also be observed. It was possible to observe predominance of fibroblasts, accompanied by rare and discrete collagen fibers presented in a disorganized tissue. In most of the samples the thickness of fibrous capsule was greater than $150 \mu \mathrm{m}$ (Figure 3E; Table 2).

\section{Ethanolic Aroeira + Bacteria - $\mathbf{3 0}$ days}

The fibrous capsule was clearly thinner and condensed, with a considerable reduction in the number of inflammatory cells (median score 1), evidencing macrophages along the entire surface of the implant area. The collagen fibers were more organized and the fibroblasts were with more elongated and thin nucleus (indicating a decrease of the collagen metabolism).
No sample presented capsule thicker than 150 $\mu \mathrm{m}$ (Figure 3F; Table 2).

\section{Discussion}

The effect of natural compounds, such as plant extracts, on the oral biofilm and their impact on microbial ecology has been widely stud ied. 9,10,11,12,20,23,24,25,26 The null hypothesis was rejected, once the extracts induced a mild inflammatory reaction after 30 days, similar to the control group. The biocompatibility of the aroeira extracts containing inactivated microorganisms were chosen, because the previously reported antimicrobial effect. ${ }^{10}$

The microbiota used in this study was composed of commonly isolated microorganisms from refractory and/or acute endodontic infections. It has been shown that associations of facultative anaerobes and anaerobes are capable of inducing inflammation. ${ }^{2,27}$ The methodology of inflammatory tissue response assessment with plant extract containing inactivated bacteria was recently reported by Machado et al. ${ }^{20}$

Some anaerobic species lost their viability within the connective tissue of mice, even before the first trial period. ${ }^{27}$ For this reason, we opted to use inactivated microorganisms to avoid obtaining false positive results. Since the objective was to evaluate the influence of products and toxic by-products of microorganisms, standardization was required.

The $P$. gingivalis, $P$. endodontalis and $P$. intermedia were previously found in periapical disease ${ }^{28}$ and they were selected due to presence of the lipopolysaccharide (LPS), which produces histolytic enzymes and the antigens induce the inflammatory response, ${ }^{29}$ so as the F. nucleatum, capable of inducing a cutaneous inflammation in rats. ${ }^{30}$ The $P$. micros is also found in pulp necrosis and periapical lesion ${ }^{28,31}$ and the E. faecalis is present in more than $80 \%$ of endodontic disease, considered a very resistant microorganism. ${ }^{32,33}$

The endotoxin from alive or dead bacteria triggers the release of inflammatory mediators such as TNF, interleukin-1, interleukin-6, interferon-alpha and prostaglandins, ${ }^{34,35}$ even in rats, since several researches have reported that virulence factors in dead bacteria are capable of inducing inflammation in animals. ${ }^{36,37}$ 
According to Lima et al. ${ }^{38}$ the aroeira has antimicrobial activity, anti-inflammatory and cicatrizant potential, which are related to chemical components present in different parts of the plant, such as tannins, flavonoids and triterpenes. Due to these properties, the aroeira presents an ample use within the medicine popular, which allows their choice in clinical studies.

Even though inactivated bacteria associated to ethanolic aroeira extract induced more edema than the other associations, after 30 days of subcutaneous implantation, the tissue response was similar to the aqueous extract.

The subcutaneous implantation method can result in an inflammatory process due to surgical trauma. ${ }^{39}$ Therefore, edemogenic analysis is a more reliable way to test biocompatibility at the early time points. The edema was similar at the 3 and $6 \mathrm{~h}$ time points for the three experimental groups. This corroborates the study by Machado et al. ${ }^{17}$ who surveyed the same extracts without the addition of microorganisms, leading us to conclude that the presence of inactivated microorganisms does not affect edema. Both the aqueous and ethanolic aroeira extract-treated groups showed a slight decrease of edema over time; however, the ethanolic extract-induced edema was greater than that induced by the aqueous extract or saline. This could be due to the initial irritating effect of ethanol, and its metabolism in the body within $6 \mathrm{~h}$.

Histological analysis showed tissue repair as a function of time, as expected for all groups. This suggests that the inflammatory effect of inactivated microorganisms is greater at the early time points, because virulence factors and components, present in the membrane and/or the bacteria capsules, and were decreased by the body's inflammatory response over time. Further, other studies have demonstrated surgery trauma-induced inflammatory responses detected by histological analysis, ${ }^{13,20,21}$ but the degree of inflammation was lower than that observed with microorganisms.

The results from this study confirmed that the tested extracts did not interfere negatively in the biological response, allowing normal tissue repair to occur. It is possible to speculate that the extracts inactivated bacterial toxins, once the aqueous extract had a beneficial effect at 7 days and both extracts had the tendency to be superior to saline after 30 days. This suggests that a component of the extracts can inhibit toxic compounds present in inactivated microorganisms.

\section{Conclusion}

Within the limitations of this study, the aqueous and ethanolic leaf extracts of Myracrodruon urundeuva containing inactivated microorganisms showed favorable tissue response, similarly to that obtained from the saline group. The slightly lower inflammation degree after 30 days for both extracts indicates a possible interference against the bacterial components, with a trend for better results than saline, suggesting future applications of these extracts in the dentistry field.

\section{Acknowledgments}

The authors deny any conflict of interest.

\section{References}

\footnotetext{
1. Kakehashi S, Stanley HR, Fitzgerald RJ. The effects

of surgical exposures of dental pulps in germ-

free and conventional laboratory rats. Oral Surg

Oral Med Oral Pathol. 1965 Sep;20(3):340-9.

https://doi.org/10.1016/0030-4220(65)90166-0

2. Fabricius L, Dahlén G, Ohman AE, Möller AJ.

Predominant indigenous oral bacteria isolated
}

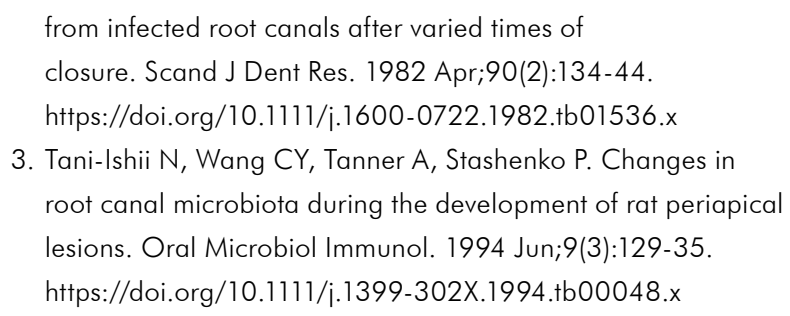


4. Pazelli LC, Freitas AC, Ito IY, Souza-Gugelmin MC, Medeiros AS, Nelson-Filho P. Prevalence of microorganisms in root canals of human deciduous teeth with necrotic pulp and chronic periapical lesions. Pesqui Odontol Bras. 2003 Oct-Dec;17(4):367-71. https://doi.org/10.1590/S1517-74912003000400013

5. Leonardo MR, Silva LA. "Curativo de demora": medicação típica entre sessões. In: Leonardo MR. Endodontia: tratamento de canais radiculares: princípios técnicos e biológicos. São Paulo: Artes Médicas; 2005. p. 978-1048.

6. Byström A, Sundqvist G. Bacteriologic evaluation of the efficacy of mechanical root canal instrumentation in endodontic therapy. Scand J Dent Res. 1981 Aug;89(4):321-8. https://doi.org/10.1111/j.1600-0722.1981.tb01689.x

7. Sundqvist $G$. Pathogenicity and virulence of blackpigmented gram-negative anaerobes. FEMS Immunol Med Microbiol. 1993 Mar;6(2-3):125-37. https://doi.org/10.1111/j.1574-695X.1993.tb00315.x

8. Leonardo MR, Tanomaru Filho M, Silva LA, Nelson Filho $\mathrm{P}$, Bonifácio $\mathrm{KC}$, Ito IY. In vivo antimicrobial activity of $2 \%$ chlorhexidine used as a root canal irrigating solution. J Endod. 1999 Mar;25(3):167-71. https://doi.org/10.1016/S0099-2399(99)80135-6

9. Dezan Junior E, Sangalli J, Gomes-Filho JE, Gaetti-Jardim Junior E. Psidium cattleianum plus $\mathrm{Ca}(\mathrm{OH}) 2$ antimicrobial efficacy against Enterococcus faecalis. In: 88th IADR; 2010 Jul 15-16; Barcelona, Spain.

10. Gaetti-Jardim Junior E, Landucci LF, Arafat OK, Ranieri RV, Ramos MM, Ciesielski Fl et al. Antimicrobial activity of six plant extracts from the Brazilian savanna on periodontal pathogens. Int J Odontostomatol. 2011;5(3):249-56. https://doi.org/10.4067/S0718-381X2011000300008

11. Brighenti FL, Luppens SB, Delbem AC, Deng DM, Hoogenkamp MA, Gaetti-Jardim E Jr et al. Effect of Psidium cattleianum leaf extract on Streptococcus mutans viability, protein expression and acid production. Caries Res. 2008;42(2):148-54. https://doi.org/10.1159/000121439

12. Ruviére DB, Machado AC, Novais RZ, Gaetti Jardim-Junior $E$, Dezan Junior E. Evaluation of the tissue response to inactivated microorganisms associated with aqueous and hydroalcoholic araça (Psidium cattleianum) solutions. J Appl Oral Sci. 2008;432.

13. Valentim D, Bueno CRE, Marques VAS, Vasques AMV, Cury MTS, Cintra LTA, Dezan Junior E. Calcium hydroxide associated with a new vehicle: Psidium cattleianum leaf extracts. Tissue response evaluation. Braz Oral Res. 2017;31:e43 https://doi.org/10.1590/1807-3107BOR-2017

14. Leite EJ. State-of-knowledge on Myracrodruon urundeuva Fr. Allem?o (Anacardiaceae) for genetic conservation in Brazil. Perspect Plant Ecol Evol Syst. 2002;5(3):193-206. https://doi.org/10.1078/1433-8319-00034.

15. Albuquerque UP, Oliveira RF. Is the use-impact on native caatinga species in Brazil reduced by the high species richness of medicinal plants? J Ethnopharmacol. 2007 Aug;113(1):156-70. https://doi.org/10.1016/i.jep.2007.05.025
16. Viana GS, Bandeira MA, Moura LC, Souza-Filho MV, Matos FJ, Ribeiro RA. Analgesic and antiinflammatory effects of the tannin fraction from Myracrodruon urundeuva Allemao. Phytother Res. 1997;11(2):118-22. https://doi.org/10.1002/ (SICI)1099-1573(199703)11:2<118::AID-PTR38>3.0.CO;2-J

17. Machado AC, Dezan Junior E, Gomes-Filho JE, Cintra LT, Ruviére DB, Zoccal R et al. Evaluation of tissue reaction to Aroeira (Myracrodruon urundeuva) extracts: a histologic and edemogenic study. J Appl Oral Sci. 2012 Jul-Aug;20(4):414-8. https://doi.org/10.1590/S1678-77572012000400005

18. Guneser MB, Akbulut MB, Eldeniz AU. Antibacterial effect of chlorhexidine-cetrimide combination, Salvia officinalis plant extract and octenidine in comparison with conventional endodontic irrigants. Dent Mater J. 2016;35(5):736-41. https://doi.org/10.4012/dmi.2015-159

19. Silva LA, Leonardo MR, Nelson-Filho P. Tratamento endodôntico de dentes decíduos portadores de necrose pulpar e lesão periapical crônica. In: Assed S. Odontopediatria: bases científicas para a prática clínica. São Paulo: Artes Médicas; 2005. p. 675-740.

20. Machado AC. Ruviére DB, Novais RZ, Bueno CRE, Jardim Junior EG, Oliveira RC, Dezan Junior E. The dynamics of subcutaneous tissue response to microorganisms associated with the extract of araça (Psidium cattleianum): an edemogenic and microscopic analysis. Braz Dent Sci. 2017 Apr/Jun;20(2):93-101. https://doi.org/10.14295/bds.2017.v20i2.1408

21. Bueno CR, Valentim D, Marques VA, Gomes-Filho JE, Cintra $L T$, Jacinto RC et al. Biocompatibility and biomineralization assessment of bioceramic-, epoxy-, and calcium hydroxidebased sealers. Braz Oral Res. 2016 Jun;30 (1). https://doi. org/10.1590/1807-3107BOR-2016.vol30.0081 PMID:27305513

22. Federation Dentaire International Commission of Dental Materials. Instruments, equipment and therapeutics: recommended standard practices for biological evaluation of dental materials. Int Dent J. 1980;30(2):140-88.

23. Leitão DP, Silva Filho AA, Polizello AC, Bastos JK, Spadaro AC. Comparative evaluation of in-vitro effects of Brazilian green propolis and Baccharis dracunculifolia extracts on cariogenic factors of Streptococcus mutans. Biol Pharm Bull. 2004 Nov;27(11):1834-9. https://doi.org/10.1248/bpb.27.1834

24. Morgan TD, Beezer AE, Mitchell JC, Bunch AW. A microcalorimetric comparison of the anti-Streptococcus mutans efficacy of plant extracts and antimicrobial agents in oral hygiene formulations. J Appl Microbiol. 2001 Jan;90(1):53-8. https://doi.org/10.1046/j.1365-2672.2001.01217.x

25. Ozaki F, Pannuti CM, Imbronito AV, Pessotti W, Saraiva $L$, de Freitas NM et al. Efficacy of a herbal toothpaste on patients with established gingivitis - a randomized controlled trial. Braz Oral Res. 2006 Apr-Jun;20(2):172-7. https://doi.org/10.1590/S1806-83242006000200015

26. Takarada K, Kimizuka R, Takahashi N, Honma K, Okuda K, Kato T. A comparison of the antibacterial efficacies of essential oils against oral pathogens. Oral Microbiol Immunol. 2004 Feb;19(1):61-4. https://doi.org/10.1046/j.0902-0055.2003.00111.x 
Bueno CRE, Valentim D, Jardim Junior EG, Mancuso DN, Sivieri-Araujo G, Jacinto RC et al.

27. Wu MK, Moorer WR, Wesselink PR. Capacity of anaerobic bacteria enclosed in a simulated root canal to induce inflammation. Int Endod J. 1989 Nov;22(6):269-77. https://doi.org/10.1111/i.1365-2591.1989.tb00931.x

28. Ruviére DB, Leonardo MR, Silva LAB, Nelson-Filho P, Ito IY. Assessment of the microbiota in root canals of human primary teeth by Checkerboard DNA-DNA Hybridization. J Dent Child. 2007;74(2):118-23.

29. Nisengard RJ, Goodman AD, Schein B. Infecções periapicais. In: Nisengard RJ, Newman MG. Microbiologia oral e imunologia. 2a ed. Rio de Janeiro: Guanabara Koogan; 1997. p. 336-41.

30. Nygren H, Dahlén G, Nilsson LA. Human complement activation by lipopolysaccharides from bacteroides oralis, fusobacterium nucleatum, and veillonella parvula. Infect Immun. 1979 Nov;26(2):391-6.

31. Gomes BP, Drucker DB, Lilley JD. Positive and negative associations between bacterial species in dental root canals. Microbios. 1994;80(325):231-43.

32. Rôças IN, Siqueira JF Jr, Santos KR. Association of Enterococcus faecalis with different forms of periradicular diseases. J Endod. 2004 May;30(5):315-20. https://doi.org/10.1097/00004770-200405000-00004

33. Paradella TC, Koga-Ito CY, Jorge AO. Enterococcus faecalis: considerações clínicas e microbiológicas. Rev Odontol UNESP. 2007;36(2):163-8.

34. Munford RS, Hall CL. Detoxification of bacterial lipopolysaccharides (endotoxins) by a human neutrophil enzyme. Science. 1986 Oct;234(4773):203-5.

https://doi.org/10.1126/science.3529396

35. Matsushita K, Tajima T, Tomita K, Takada H, Nagaoka

$S$, Torii M. Inflammatory cytokine production and specific antibody responses to lipopolysaccharide from endodontopathic black-pigmented bacteria in patients with multilesional periapical periodontitis. J Endod. 1999 Dec;25(12):795-9. https://doi.org/10.1016/S0099-2399(99)80299-4

36. Gaetti-Jardim Junior E, Luvizotto MCR, AvilaCampos MJ. Virulence of oral Fusobacterium nucleatum from humans and non-human primates in mice. Braz J Microbiol. 2000;31(2):146-50. https://doi.org/10.1590/S1517-83822000000200016

37. Dalen PJ, Deutekom-Mulder EC, Graaff J, Steenbergen TJ. Pathogenicity of Peptostreptococcus micros morphotypes and Prevotella species in pure and mixed culture. J Med Microbiol. 1998 Feb;47(2):135-40. https://doi.org/10.1099/00222615-47-2-135

38. Lima MR, Luna JS, Santos AF, Andrade MC, Sant'Ana AE, Genet JP et al. Anti-bacterial activity of some Brazilian medicinal plants. J Ethnopharmacol. 2006 Apr;105(1-2):137-47. https://doi.org/10.1016/i.jep.2005.10.026

39. Rutberg M, Spangberg E, Spangberg L. Evaluation of enhanced vascular permeability of endodontic medicaments in vivo. J Endod. 1977 Sep;3(9):347-51. https://doi.org/10.1016/S0099-2399(77)80064-2 